\title{
Examining Factors That Obstruct the Practice of Learner-Centered Approach in Teaching Speaking Skill in English Language Classroom: The Case of Five Government Primary Schools in Wolaita Sodo City
}

\author{
Amanuel Kidane Albore \\ English Language and Literature, Wolaita Sodo University, Wolaita Sodo, Ethiopia
}

\begin{abstract}
This study was to examine factors that obstruct the practice of learner-centered approach in teaching speaking skill in English Language classroom in grade seven and eight of Wolaita Sodo City. It also aimed to explore the restraints that inhibit the practice of this approach. The study was conducted in five government primary schools. Seven English language teachers who are currently teaching at grade seven and eight level participated in the study. The instruments used were interview, written reflection and classroom observation. The qualitative data generated through these instruments were analyzed and categorized thematically and presented in a narrative form. The results of the study indicated that teachers were not practicing learner-centered approach to the level that the policy advocates because there were various factors that encumbered the practice of learner-centered approach in teaching speaking skill in English Language classroom. The first factor was students' background such as mother tongue interference, lack of vocabulary, lack of self-confidence, and low level of motivation. The other factors include time constraints, large class size, seating arrangement and lack of adequate teaching materials. The findings also suggest that the teachers in the study lack sufficient trainings on how to apply the learner-centered approach. Therefore, it was recommended that teachers should be provided with communicative activities on how to apply the learner-centered approach.
\end{abstract}

Keywords: Communicative Language Teaching, obstruct, Learner-Centered Approach, Speaking skill DOI: $10.7176 / J L L L / 62-01$

Publication date: November $30^{\text {th }} 2019$

\section{INRODUCTION}

Communicative Language Teaching is an effective method of developing learner-centered approach because it gives learners the opportunity to practice English language appropriately which increases their language achievement (Harmer, 2006). This means, the role of learner-centered approach in teaching speaking skill is important as it allows students to actively involved in the learning process and internalizes the language. Accordingly, the goal of CLT is, thus, meant to promote active participation of students in English language learning classrooms thereby booming learners' communicative competence. Likewise, realizing the need to maximize the learner's English language abilities the education and training policy has mandated teaching requirements for English language classrooms to shift into the more learner-centered approach of teaching and emphasize developing students' speaking proficiency because speaking skill is one of the abilities to carry out conversation or communication. It also is an interactive process of constructing meaning that involves producing, receiving, and processing information (Brown, 1994; Burns \& Joyce, 1997). Thus, students should have the ability to speak English in order that they can communicate with others, and teaching speaking skill is focused on making student active and creative, so that the great part of time in the process of learning speaking is dominated by students.

That's why, it can be realized that CLT is an essential method of learner-centered language teaching, particularly speaking that give student's ample opportunity to practice and improve their speaking skill. However, the practice of learner-centered approach in ELT classrooms is ineffective because the teacher-dominated approach is still reinforced in the classrooms. According to recent studies, (Verwimp 1999; Tirualem, 2003; Derebssa, 2005; Zweiers, 2007), the commonest teaching method in the primary schools of Ethiopia is still the traditional approach, where students just need to listen, and they have no time to practice their speaking skill. That is to say, students are passive learners in this traditional teacher-centered approach. For example, the study by Derebssa (2005) that aimed at finding the extent to which the learner-centered approaches of teaching and learning were employed in Ethiopian primary schools and identifying the factors that affect its practice, has found out that the teacher-centered approach in which teachers talk and students listen dominate most classrooms. There are surely various factors that obstruct the practice of learner -centered approach in teaching speaking and which makes students communicative competence achievement unsatisfactory. A traditional limitation to developing students' communicative competence is the inadequate interaction between teachers and students. Teachers simply spend much time lecturing while students take notes and seldom participate in class (Tirualem, 2003). In other words, most of teachers still use the traditional methods of teaching English so that teachers 
seldom set up interesting activities to encourage their students to have active and effective English learning.

Conversely, in most primary schools in Ethiopia large class teaching is still common practice. It is widely admitted that teaching English to a large class has disadvantages over a small class. So, in most part of Ethiopia large classes are still reality and pose particular challenges to ELT teachers in developing CLT methods. This fact suggests a definite necessity to study and explore the existing reality about how the learner-centered approach is being practiced by English teachers in teaching speaking skill. This research is different from previous studies in that it focused to explore the challenges that obstruct the practice of learner-centered approach in teaching speaking skill in English Language classroom.

\section{Statement of the Problem}

Speaking is the most important skill among four skills (listening, speaking, reading, and writing) because people who know a language are referred to as speakers of that language Ur (1996). It is recognized as critical for functioning in an English language context, both by teachers and by students. Hence, the ability of students to communicate naturally in English is one of the long-term goals that language teachers would like to achieve in class. Indeed, it is a demanding task for language teachers to provide sufficient inputs for students to be competent speakers of English. Usually, students feel insecure about their level of English and they face problems communicating as well as expressing themselves in English language. As a result, they rather remain silent as they are in fear of making mistakes and do not show active participation in speaking lessons. Therefore, Communicative language teaching should be adopted by teachers in language teaching to improve students speaking ability (Harmer, 2006; Jones, 2007).

The teacher-centered approach makes students passive in learning English due to the fact that most of the talking time in the class was dominated by the teacher, which has left a very little opportunity for students to practice speaking. But in a student-centered speaking teaching and learning process students dominate the great part of time, and this makes students active and creative in their learning. Therefore, the effective practice of CLT is considered to be beneficial for developing students speaking abilities. That means, it provides students with different speaking activities such as group work, pair work, role plays, oral presentation, and dialogues that enable students to attain communicative competence. As to Brown, (1994) and Richards (2006a), Communicative language teaching activities provide more active, participative, and creative learning environment that involves students in decision making process. Thus, teachers need to facilitate effective use of communicative activities in speaking classrooms to offer students with ample time and diversified context to practice the language use.

Accordingly, as has been discussed in the previous section of this chapter, in most ELT classrooms there is a continued tendency toward teacher-centered classrooms despite reforms that promote a learner-centered approach. Thus, the researcher was interested to explore the current practice of learner-centered approach in light of the policy by English language teachers in teaching speaking. Hence, the problem presented in this paper was examining the practice of learner-centered approach in teaching speaking skill in ELT classrooms.

Objective of the Study: The major objective of the study was to examine factors that obstruct the practice of learner-centered approach in teaching speaking skill in English Language classroom.

\section{Research Design and Methodology}

Research Design: This study was a descriptive one that used qualitative methods and data, which has helped the researcher to come up with important findings for the study. Because qualitative research was important in providing complex textual descriptions of how people experience a given research issue. Accordingly the researcher was able to study the research problem in detail, holistically and in context where information from the participants was evaluated and summarized logically to come up with rich textual descriptions about their experience of employing learner-centered approach.

Description of the Study Area: There were about twenty government primary schools in Wolaita Sodo City. For this study five primary schools were selected based on their place relevance to get participants of the study together in one area so as to make the interview simple and valid. Moreover, the researcher has a good background information about these schools because he was well acquainted with some teachers in these schools and this allowed for a relaxed, honest, and fruitful atmosphere to develop quickly for this study. Thus, the five schools selected by the researcher for this study were government schools and they were Giorgis Primary School, Ligaba Primary School, Damot Ber Primary school, Tigil Fire Primary School and Abiyot Chora Primary School. All schools were primary schools (grade 1-8). English language was taught as subjects that are offered by Wolaita Sodo City administration, for English become the medium of instruction for all subjects.

Participants of the Study: Participants of this study were grade 7 and 8 English language teachers in Giorgis Primary School, Ligaba Primary School, Damot Ber Primary school, Tigil Fire Primary School and Abiyot Chora Primary School in Wolaita Sodo City. The researcher selected these participants for the purpose of getting experience-based reflections or exploring data about the practice of the learner-centered approach from the 
teachers' perspectives which made this research rich as well as pertinent in its data findings and answering the research questions set by the researcher. Because the researcher believes that unlike other bodies involved in the education sector, teachers always work within a puzzling or challenging environment as they were always very closer to every educational issue in the teaching profession than anybody else so that they can be considered as a big source of information. Broadly speaking, they can provide substantial contributions to filling out the structure and character of the experience under investigation.

Data Sources and Sampling Techniques: In Wolaita Sodo City, there were about twenty government primary schools. Only five of them were selected purposely as sample schools. This means, the researcher has a good background information about these schools because he was well acquainted with some teachers in these schools and this allowed for a relaxed, honest, and fruitful atmosphere to develop quickly for this study. From these five schools, Giorgis Primary School, Ligaba Primary School, Damot Ber Primary school, Tigil Fire Primary School and Abiyot Chora Primary School, the researcher used second cycle and only grade 7 and 8 have become the target groups for the study. These two grade levels were selected because starting from grade seven the medium of instruction for all subjects, was English and, therefore, the researcher was interested to see the seriousness of the research problem at these levels.

Comprehensive sampling technique was used to select participants for the interview and written reflection data gathering process. This was done in order to increase the number of participants for the purpose of incorporating teachers from different school with different experience and feelings, because the researcher hoped that it could be helpful to obtain important data findings for the study. Thus, among seven English language teachers teaching at this grade levels in these five schools, all of them were taken in the above two major data gathering processes and they have provided significant accounts of experience under investigation. Random sampling strategy was used to select one section from each school for classroom observation. This strategy was opted because observation was used to triangulate the other two major methods of gathering data on teaching and classroom practices. The researcher used three classroom observations to get important information in order to support the data collected through the other two tools.

Instruments and Procedures of Data Collection: For the purpose of collecting appropriate data, the researcher opted for three research instruments: interview, written reflection, and classroom observation. The first two were used as a major data collection instruments while classroom observation was used as a supplementary data collection tool in order triangulate and to collect a comprehensive data for this study. They were all of great help in generating data that was useful to answer the guiding basic questions of the study.

Methods of Data analysis: The purpose of using an inductive approach was to create meaningful links between the research objectives and the findings, and lead to the framing of a theory about the experiences that are evident in the raw data. The researcher believed that it has provided a convenient and efficient way of analyzing the qualitative data for the research purpose. Inductive approach is an effective method of qualitative data analysis because it involves reasoning, allowing for modification of concepts and relationships between concepts occurs throughout the process of doing research, with the goal of most accurately representing the reality of the situation (Patton, 1990).

Therefore, the data that was gained from the interview, written reflection and classroom observation were analyzed qualitatively and the study has used inductive analysis process for coding and classification of the data. Accordingly, a list of data was compiled according to what issues were addressed based on the research objectives. The researcher analyzed and categorized the information discussed. The notes were also compared with the literature review done in this study. Issues and suggestions were compared based on opinions from teachers gathered by the two major instruments and classroom observation. Then the researcher attempted to summarize the findings from these three instruments which allowed the researcher to develop suggestions or recommendations about how to improve the practice of learner-centered approach when teachers teach speaking skill in ELT classrooms.

\section{RESULTS}

\section{Challenges Teachers Face in Applying Learner-Centered Approach}

In this section of the chapter the data about teachers' practice of learner-centered approach in light of the policy was presented and discussed with regard to their actual classroom practices. There are some practical challenges that participants have forwarded as the reasons not for applying the learner-centered approach in their classroom even if they asserted theoretically about the values of incorporating learner-centered approach in language classrooms. The challenges teachers face in their practice are:

\section{A. Inadequate Trainings}

Empowering teachers with the necessary skills they require for proper practice of learner-centered teaching and learning is very important as different studies suggest. Participants in the study (T4, T5, and T6) stressed lack of adequate trainings on how to apply the learner-centered approach as a major challenge. During the interview, for example, one participant stated that: 
I feel applying learner-centered approach is useful in language classroom to make students understand by helping each other... using their potential they can take care of their own learning by themselves. However, even if I know many things theoretically from my experience and reading about this approach I did not use it always. Most of the time I use the traditional method... I did not get any special preservice training on how to apply the learner-centered approach. And also I have taught for the last thirty years and until now only one workshop that I have get last year with my colleagues (T4).

This reflection seem to suggest that the teacher was not well equipped with the necessary skills on how to teach speaking skill in learner -centered approach, the absence of adequate pre-service training has significantly influenced his teaching way. Because without having proper training it was impossible for the teacher to shift from the traditional classroom practice to the learner -centered teaching and learning method. Regarding inservice trainings the participant received only one training in the form of workshop which is relatively short, just for one week, which appears to be inadequate for the teacher to practice the learner-centered approach effectively.

According to the education book published by UNICEF (2000:22), training can help teachers to improve a number of aspects in their teaching, and training can change teachers "attitude such that their students improve their learning, as they become a best learners of language through that innovative teaching". That is, both preand in-service trainings have a paramount importance in providing teachers with the necessary skills of the teaching methodology as well as how to adopt it in their classrooms. Another participant from the written reflection has written that he was failed to apply learner-centered approach because he was not taught by teachers who use the learner -centered approach:

When I learned my Degree in summer university program I have learned many things about learnercentered approach. But this pre-service training is not as clear as enough for me because the teachers themselves taught us by using the traditional method. So I do not use the new approach in my classroom always, because during my stay at university for learning our teachers themselves prefer to teach us in the old teacher-centered method and some of them half by half use Amharic language (T6).

This was a typically important view that may indicate an evidence of poor pre- and in-service training that English teachers in these schools have had and still receive. This has made a considerable contribution to the insufficient practice of learner-centered approach in teaching speaking skill. Apart from that, the way the teachers were trained has affected the way they are teaching, because they teach as they were taught. Teachers who are themselves products of the traditional teaching and learning approach are not required to be effective implementers of the learner-centered approach as well as effective English speakers (Jones, 2007).

During classroom observation only one teacher (T7) was observed using different learner-centered teaching methods such as groups, peers for students' active involvement and participation in the speaking lesson learning, and where relatively the teacher becomes a facilitator. But T2 and T5 were not observed encouraging students' participation for independent learning rather they dominate most of the class time, and frequently use Amharic for instruction and the students too. One can, therefore, draw certain implications as regards the classroom practices of these teachers, that they were still using the traditional teaching method which indirectly revealed that they have not received adequate trainings on how to apply the learner-centered approach. The findings of this study showed that the participants seem not to have adequate trainings (both pre- and in-service) about the learner-centered approach and how to practice it in teaching speaking skill.

\section{B. Time Constraints}

Participants believed that the learner-centered approach is better than the teacher-centered approach; however they explained that this approach takes a lot of time to finish one speaking task in a class. As a reason mostly they use the traditional approach of teaching to finish the text book in the time provided for them. During the interview one participant stated this challenge as follows:

Even if learner-centered approach is good for teaching speaking lessons, most of the time I use the traditional method of teaching. Because if you apply learner-centered approach it takes a lot of time and you cannot cover the textbook in the academic year or the schedule provided for you. Besides I teach 30 periods in a week and in such condition it is difficult for me to apply this method because of the shortage of time I have to be prepared. So we use this approach rarely or we cannot apply it always in teaching speaking lessons... most of the time we use the teacher-centered approach (T6).

This seem to imply that teachers have an excessive teaching load which may have a negative impact on their classroom practice because if teachers do not have a reasonable teaching periods they cannot adopt learnercentered teaching methods. That is, time does not allow the teachers to design communicative activities by themselves as well as to prepare themselves properly so as to teach speaking activities effectively. The following quote is taken from the written reflection:

The time allotted for each period is a major constraint that must be considered. With a large number of students in a class it is difficult to cover one speaking lesson in one class if I use the learner-centered approach. Every student need to show their involvement in speaking activities and want to get feedback 
about their performance. But the time allotted for one period is 40 minutes so it is impossible to give chance for all students to present what they have done in groups or pairs (T7).

What can be understood here is that this teacher seems to have a belief that time was not sufficient to engage all students in whole class discussion when students done speaking activities in group or pair. But here the teacher can encourage students to evaluate each others' performance, discuss and come to a group decision. In learner-centered teaching classrooms where group or pair work was used students can develop cooperative and independent learning through self or peer-evaluation (Richards and Rodgers, 1986; Harmer, 2006). Therefore, in such a way the teacher can play the role of monitoring and there is no need to give feedback to each student that help to manage the teaching time appropriately.

Unlike the above two reflections on time constraints due to excessive teaching load and the short time given for teaching speaking lessons, another participant, from the interview, illustrated time constraints due to the nature of speaking lessons in the students textbook as too much time taking than the other skill lessons:

...the speaking tasks that are given in the student textbook take a long time to do them effectively. And this will create a problem on the other skill lessons to be covered on time, thus I will be forced to shorten the time that I allotted for teaching speaking. For this reason I rush to cover all chapters and mostly I use the traditional method of teaching for this purpose even if I know that this have an impact on the effectiveness of my speaking skill teaching (T1).

According to the above reflection it seems that there is a mismatch between the speaking lessons provided in the textbook and the scheduled time for teaching because the length of speaking lessons might affect the way this skill and other language skills were taught as teachers focus was diverted to cover the portions indicated in the syllabus. In support of this idea another participant has written similar points in the written reflections sheet in the following way:

Ifeel learner-centered approach is appropriate in teaching speaking skill but because of the shortage of time I use this approach at least one time in 15 days or in a month where the speaking lessons are suitable for me. Because it is unthinkable to teach speaking without forming groups and pairs, and without having enough time for students to practice (T3).

On the basis of the above reflections it can be implied that participants have the view that the speaking lessons and the time allotted for do not much each other. Accordingly, compared to the teacher-centered approach the use of learner-centered approach was considered to be time taking, and it was due to this fact that teachers might mention their worries that they could not complete the lessons on the time provided for them if they use the learner -centered approach.

Thus, participants response indicate, time constraints due to the length of speaking tasks, excessive teaching load, duration of teaching time and the need for covering the vast portions which have created a shortage of time on them to apply learner-centered approach. However, it would have been possible to make teaching learner centered despite these constraints, if students had learning materials such as the textbook at hand. If teachers use the textbook creatively, adopting it in various ways to suit the situation they and their students were in; it would be possible to teach speaking lessons with the use of a variety of communicative activities that promote learnercentered approach (Brown, 1994; Hedge, 2004; and Jones, 2007).

During classroom observation the researcher has found out that all students were provided with the textbook, but some students do not bring their books in to class which shows the teachers inability to manage their classroom conditions appropriately. Thus, it would have been possible for teachers to cover the portion through provision of group work, pair work, home work, and reading assignments, which were also methods of active learning. Classroom observation results also demonstrate that it was only one teacher (T7) that relatively observed using learner-centered teaching methods appropriately, other teachers (T2, and T5) were not observed providing their students with speaking activities that promote learner -centered approach appropriately.

For example, participant (T2) was observed in teaching a speaking lesson (topic-Expressing future wish) with the use of dialogues and individual presentations which can be characterized as activities that promote learner-centered approach. However, the teacher did not use these methods meaningfully in a way that offer students to practice speaking actively, rather the teacher just ordered students to prepare themselves for five minutes before presenting the dialogue. The teacher started with explaining and demonstrating about the language forms used in the activity without involvement of the students. Then the teacher pose some questions to students and some individuals answered while other students sat passively. Students were not seen spending some time thinking and discussing in pairs and groups to answer the questions. Next, the teachers instruct students to practice the dialogue on the textbook, first in pairs and then individually. But students were made just to read what was on the textbook rather than using it as a model to develop their own dialogue, the teacher was not seen moving around to assist students. Thus, it was evident that, even if this lesson seemed to provide active students participation, the classroom practices of this teacher was characterized by teacher-centered approach.

\section{Students Background}

Participants have listed the following issues related to students' background as a challenge in applying learner- 
centered approach in speaking teaching class:

\section{Mother Tongue Interference}

Mother tongue interference among students was the problem participants raised; for example a participant from interview has revealed this issue as follows:

Students like to speak in Amharic when they learn speaking lessons and work activities in groups. This is related to the students' background, the way they brought up learning English language using their mother tongue as instructional language in English class. And this has affected the participation of the students in communicative activities (T3).

One can, therefore, understand that students' mother tongue interference that may come as a result of the way they have been taught in lower classes could affect the practice of learner-centered approach. Classroom observation results also showed that students need to use their mother tongue and their teachers were not observed trying to encourage students to try to use English; rather they were also using it. This was against the principles of CLT because the use of L1 has an impact on students speaking skill achievement (Schmitt, 2002; O’Neill and McMahon, 2005).

For example, among observed participants, participant (T7) was observed using provisions for group work and cooperative learning, and also this teacher used some words of encouragement and praise to motivate students to share their thought and ideas in English during group work and classroom discussion. The teacher also moved around to monitor and support students, but when the teacher was nearer students tried to discuss in English and when the teacher moved to monitor another group the other groups turned their discussion in to their mother tongue. This may imply that students like to use their mother tongue to express their ideas efficiently because their English speaking ability was not sufficient. But the teacher was seen motivating and helping the students, and as a result gradually the students may develop their English speaking ability. According to Wallace "et al.", (2004) teachers can play an important role in speaking skill learning classrooms by encouraging and supporting students to use English as much as possible, especially students can be able to benefit from using English when teachers motivate them to practice speaking through different communicative activities in the classroom.

In contrast, the other two participants in the classroom observation (T2 and T5) never tried to encourage students to use English or to stop the use of Amharic by the students, and half part of the classroom discussion was through Amharic by these teachers. And mostly students were made to listen passively and to answer questions led by the teachers. The following quote was also taken from the written reflections:

... when I try to teach speaking lessons in a learner-centered approach in my class only few students participate in the class so I prefer to use the old method and instruct them with Amharic in order to make them all participate in the speaking lessons (T2).

The above results may indicate that teachers and students in these classrooms make frequent use of Amharic language during English speaking lessons and this has affected the students speaking skill achievement. Richards (2006a) suggested that, in communicative language teaching approach teachers are expected to use English, and through engaging learners in communicative speaking lessons students can avoid their native language use. Thus, teachers were expected to speak English as much as possible in the class, especially since if they do not, students will not see the need to speak too much English either (Jones, 2007; Skehan, 1996).

Results of classroom observation also confirm the use of Amharic by teachers and students. For example, participant (T5) was not observed encouraging and supporting students to speak in English. The teacher begun by introducing the lesson, and then asks students some questions from the previous class lesson. But except for a few students, most of the students were not seen raising their hand for answering the questions. Then teacher the shift the instruction in to Amharic, and the discussion goes on with Amharic for some time. At the end of the class two students asked questions, both used Amharic and the teacher was not seen motivating them to try to speak in English, rather he used Amharic to answer the questions raised from students. These results may imply that the classroom practices of this teacher tend to be the teacher-centered.

Different studies revealed that one thing that can drive teachers wild was when their students were apparently unwilling to use English in their classroom, especially during communicative activities. No one was in any doubt that students may use their mother tongue in class, whatever teachers say or do; the question is whether teachers should try and stop it (Schmitt, 2002; Richards, 2006b). However, there are many actions which teachers can take to promote the use of English among students, especially in communicative activities.

For instance, Harmer (2006:132), stated that there will be more chance of students making the classroom truly English themselves if teachers "...create an English atmosphere and use persuasion" during speaking activities. This means, if teachers create an English environment, making English the classroom language as well as the language to be learnt and also if they spend a lot of their time going round to students and tell to use English it ensures that most students are speaking English most of the time. Accordingly it was advisable that teachers need to persuade students that they will benefit from speaking English in their English class, which may be their only chance to speak English. However, classroom observation results demonstrate that except one 
participant, the other participants were not observed using such methods that motivate students to speak English in the classroom

\section{Shortage of Vocabulary}

Participants in the study raised the shortage of vocabulary that students have as a challenge. For example, it was discussed by participant from the interview in the following way:

Students do not have a sufficient amount of vocabulary when they want to express their idea which has affected their speaking ability. They also have a problem of forgetting the vocabularies they have studied because they do not use them in their day to day activities. However, they are very interested to know and learn that new word and most of the time they ask me how to use that word in English. And I tell them how to use that word in English appropriately but it is time taking (T7).

This result may indicate that students have a lack of enough vocabulary to speak out their ideas in the classroom that can hinder their involvement or active participation in the speaking skill learning and teaching process. Another participant from the written reflection has written about why this problem has affected the practicability of learner-centered approach:

Lack of students language ability will affect the practicability of this approach because if students unable to participate in the classroom learning... teachers dominate all the activities and students cannot get the chance to practice speaking skill in the class (T6).

This would seem to imply that students have a shortage of vocabulary so that they cannot actively participate in class discussions. Similarly, classroom observation results have also demonstrated that students need to speak in their mother tongue which indirectly may show the students shortage of vocabulary to speak English. Brown (1994) stated that providing students with different communicative activities to work in group can help them to discuss and learn from each other. Thus, when students work in pairs or in groups they would benefit from the experiences of each other and so that they can develop their vocabulary that would enhance their ability to speak (Thompson, 1996; Savingon, 2002). Hence, arranging students in pairs or groups during speaking activities have a significant contribution for students to develop their vocabularies. Because in communicative activities students have enough time to practice speaking or use the language as they will be engaged in discussing on different issues related to their own experience. They also share their vocabularies, points of view, and interests (Paulston and Bruder, 1976).

However, results from the classroom observation evidenced that participants rarely use groups and pairs or other cooperative learning activities in their class. It was only one participant (T7) that provided students with group work activities, but still some students were seen using their mother tongue when discussing in group. These students seem interested to speak but find it difficult to express themselves due to the shortage vocabulary they have. The teacher was seen moving round to assist students with new vocabulary. At the end of the lesson the teacher wrote new words raised by students during group discussions and instructed students to study their meaning from dictionary in their home. This seems to indicate that the response of this participant in the interview was not contradicting with his classroom practice.

\section{Lack of Self-Confidence}

Students' lack of self-confidence is the other problem raised by the participants. This problem was written by a participant from the written reflection as follows:

Most students in my class do not have self-confidence and as a result they are not active participants in different speaking lesson activities. Especially the girls are not confident due to some socio-cultural factors, the society encourages shyness and they under estimate themselves. This hinders students not to actively participate in speaking teaching classes...it will become difficult for us to teach in a studentcentered approach (T1).

From this reflection one can understand that the students' lack self-confidence to speak English that may have a negative impact on the teaching and learning of speaking lessons and on the active participation of students. But students' lack of confidence can be better improved if teachers involve their students in the teaching learning process, active participation of students in pair and group work was needed in doing so. However, evidence from classroom observation showed that only one teacher that relatively used communicative teaching methods.

For instance, in (T2) classroom observation, the teacher was seen using dialogue and individual presentations, but it was not effective due to the absence of appropriate class management by the teacher. In other words, students were not made to actively participate in the class, the teacher was not seen supporting the students to discuss on the dialogue. The teacher tried to use some brainstorming questions, which were not openended to offer students for discussion. Students were not made to compare their answers and share their ideas, rather the teacher read each questions with few students raising their hand to answer and then the teacher gave the correct answers. Students' mistakes were directly corrected by the teacher so that students did not have the chance for peer evaluation. The same hands were raised in the class and most of students were not seen participating, which may imply their low level of confidence. The teacher did not provide students opportunities 
to practice speaking and never tried to encourage students who do not participate in the class. This means that the teacher failed to create a class atmosphere rich in communication where students actively discuss on the activities.

According to (Lea "et al.", 2003) the use of cooperative learning methods can help to reduce students' anxiety to speak up in front of the class. That means providing opportunities to practice communicative activities in pair or group work will make students to reduce their fears and able to improve their speaking ability. Studies suggest that, students who have never worked together before may need a lot of support and encouragement to begin with. And communicative activities such as dialogues, conversations, oral presentations may help them to feel more confident; if teachers use them effectively (Richards, 1990; Widdowson, 1978).

All students need to feel ready before they can work together with confidence, and this confidence will grow little by little as students successfully share ideas and experiences when they do work together (Paulston and Bruder, 1976). However, the results of this study revealed that participants were not accurately exercise active learning methods when they teach speaking lessons. Thus, there was a little room for students to share their ideas and experience in pair and group discussions which was useful for developing their confidence as well as speaking skill.

\section{Low Level of Motivation}

Participants have put students' low level of motivation as a challenge. For example, a participant from the written reflection wrote the following:

Most of the time, the major challenge that I come across in implementing learner-centered approach is students low level of motivation to speak English. In their culture, especially the girls are not encouraged to express themselves equal as boys, the society accept shyness of girls as a good cultural value. When we teach speaking lessons these girls do not participate in doing speaking activities because of this problem (T4).

It can be implied from the above reflection that the cultural images associated with unequal treatment of females, or the views the society hold for females has affected the student's motivation in their language learning, which in turn have a profound effect on the students speaking ability. A participant from interview discusses this challenge as follows:

Girls are expected to keep silent or speaking for them is assumed as a sign of disrespecting the culture of the society, and due to this cultural factor female students do not participate in speaking teaching classes. Even if we try to motivate them to practice speaking in the classroom they have a very low participation... this problem among students has become one barrier to communicate in the classroom and also to teach speaking lessons in a learner-centered approach (T3).

This response seems to suggest that the cultural attitude of the society that discourages females' involvement in the societal communication has an influence on the degree of motivation the student brings to class. That means they bring with them attitudes from the society they live in, and this has greatly affected their motivation in the language learning class. The researcher found out that in the three observed classrooms the number female students exceeds the number of males, but their participation in the speaking lessons learning was not satisfactory compared to that of males which may show the influence of this problem. A very few number of female students were seen participating in the class, while majority of them show some resistance or unwillingness to speak English. Another participant from the interview has reflected about the negative impact of this problem on the practicability of learner -centered approach as follows:

...in speaking teaching class if students become passive listeners they will not be creative, and cannot develop their self-confidence because they did not able to practice the language due to the presence of cultural influence (T1).

This result may suggest that the motivation of female students suffer from the cultural attitudes of the society that hindered their active participation in the speaking lessons teaching and learning classrooms. The presence of students' low level of motivation due to their cultural influences in language teaching classrooms would seem obvious that can be considered as a constraint to the teaching of speaking skill lessons. Harmer (2006:52) stated that cultural images associated with language learning have a profound effect on the degree of motivation the students bring to class, “...students attitude to language learning will be greatly affected by the influence of people who are close to them". But teachers can initiate and sustain students' motivation if they promote learner-centered learning and teaching methods in their class (Taylor, 1983; Richards and Charles, 1994; Jones, 2007).

The use of CLT methods considered being important to increase students motivation, here it was worth pointing out that the benefits of group work and pair work but rarely used by these teachers as the findings revealed. Some studies suggest that it was possible to stimulate a better exchange of ideas by putting shy students in groups rather than in pairs (Hymes, 1970; Cooper and Robinson, 2000). Others consider rearranging groups regularly was important to develop shy students speaking abilities. Jones $(2007: 8)$ has stated that weaker and shyer students should not always be with the same group members, because "new experiences with different 
partners can help such students to develop more confidence". Furthermore, the determination of the teacher to encourage students so as to motivate them in order to practice speaking through communicative activities was helpful to bring gradual change among these shy students. Because arranging weak or shy students with a variety of partners or in different groups was significant to help them develop confidence and increase their level of motivation.

\section{Lack of Exposure}

Lack of appropriate exposure to practice the language on the part of students was also raised by participants as a challenge. The following quote from the written reflection shows:

Lack of exposure or the so called ideal environment in which students practice and develop their language through communicating with their friends, family and the like is also a problem. Students do not practice speaking when they are out of the teaching classroom. So this has brought its own impact on students' active involvement in the class and in practicing learner-centered approach in speaking skill teaching (T6).

This reflection shows that students' inability to use or practice the language outside the class was considered to be a problem that can hinder the teaching and learning of speaking skill. That is, students did not have favorable atmosphere in which they practice the language in their daily life situations. Participant from the interview elaborated this challenge as follows:

...It has a great impact on students' accusation of a language and on the practicability of a language lesson, especially on speaking skill. If the students lack all the conducive atmosphere and condition in which they master the language it will hinder students not to effectively engage in the class, and use the language. Again this problem have it is own impact on the teaching learning process, not only on English but also on other subjects plus on the teacher of English, he/she cannot fully implement the desired lesson in a desired way. The teacher is limited to use only the teacher-centered approach with a few students involvement...that is all (T4).

Thus, it can be understood that lack of exposure to the language may hinder the practice of learner-centered approach as students cannot practice the language outside classroom. However, as most students in Ethiopia do not have the opportunity to use English in their daily life as people in English speaking nations do, classroom learning and training was still the preferable approach for them to master the language. Therefore, sufficient and effective training in class was still indispensible for most English learners in Ethiopia. The use of communicative language teaching approach was considered to be important for such learners speaking ability achievement (Jones, 2007).

In CLT there was a variety of activities which give a wide exposure to students to practice their speaking skill (Nespor, 1987; Wallace "et al.”, 2004; Richards, 2006b). For instance, the practice of speaking activities through group work provides noticeable interaction in the group as the students gain confidence to overcome the fear in speaking activities. This means group work was an attractive idea to increase the amount of students' talking time or exposure to the language. Students use the language to communicate with each other and more importantly, to cooperate among themselves. But classroom observation results showed that, among three observed participants two of them were seen practicing the teacher-dominated approach that left students with no chance to practice the language in the classroom through collaborative learning.

\section{Class Size}

Analysis of data from the participants of the study showed that teachers regard class size as a challenge in practicing learner-centered approach. For example, participant from the interview stated that:

The major challenge in teaching speaking lessons is class size. There are 62 students in my class, that's too many. This large number of students is a big challenge to teach speaking skill in a learner-centered approach because it is difficult to engage all these students in speaking activities (T2).

The above result indicate that the participant belief about the large number of students in his class as a challenge to apply learner-centered approach. But even in classes with large number of students there are many classroom techniques that can be used to promote this approach. Similarly, the following was taken from another participant in the interview shows:

In my experience, most of the time when students are given a task to work in groups or pairs they need feedback and encouragement. But in a class where there are more than 60 students it is difficult to engage all groups in class discussion. Assume that I arrange these students in 12 groups with 5 students in 1 group to do speaking activities. But you cannot give chance to all these groups to present their work and then to give them feedback. Because the time is not enough, 40 minutes of one period is not enough, so frequently I prefer to use the traditional method of teaching (T5).

It was evident that these two quotes from the participants shows that classrooms were characterized by large class size and this large number of students in a class was perceived by these teachers as a challenge to practice learner-centered approach in teaching speaking. Many studies revealed that, in order to adopt or apply a learnercentered approach, the number of students in a given class should be reasonable so that teachers able to identify 
each student by name; give feedback to the performance of students on time and all students got chance to express their view (Harmer, 2006). Moreover, at least the number of student and the size of the classroom should fit each other so that the teacher gets passage to go within the group and guide or monitor students' activities. At the same time, students should also get enough space to move freely while forming group for discussion and backing to their seat (Hymes, 1970; Dorneyeize and Thurrell, 1994).

However, from the researcher's experience during classroom observation, these all conditions were not observed in the context of these schools. The researcher has found out that the class size in the classes selected for the study ranged from 50-65 students in each class. In this way, the place for teacher to step on was limited to the front side of the room. The researcher witnessed this condition from his experience of classroom observation with at least three classes. The classes were too narrow and the immovability of furniture can also be a challenge for these teachers to arrange students in groups for communicative activities. In opposite of the above two participants reflections, one teacher, the one observed relatively able to adopt the learner -centered approach in his teaching with 64 students in his class, argued that class size should not be taken as a big challenge. This participant from the written reflection pragmatically wrote:

I do not believe by the idea that large class size prevents teachers from applying learner-centered approach. Even if there is large number of students in my class I do not consider it as a big challenge, because I arrange students in to groups. And the use of group and pair working has helped me to create a learner-centered speaking lessons teaching. I can say... I am successful in implementing this approach around seventy percent (T7).

This reflection may imply that the learner-centered approach can be practiced even in large class situations. But contrary to the above participant, the other six participants considered large class size as a challenge to practice learner-centered approach which indirectly may show these teachers still have inadequate skill on how to apply active learning techniques in large class size situations. Evidence from classroom observation also shows that it was only one teacher (T7) that appropriately manage students in to groups for discussion, most groups were seen engaged in classroom speaking activities with the teacher motivating and monitoring the students discussion.

The literature in learner-centered teaching reveals that large number of students in ELT classrooms has great practical difficulties in applying CLT method. Because firstly, it greatly reduces the opportunities of students in the classroom to take part in the oral language practice; secondly teachers may have difficulty in adjusting classroom atmosphere; and thirdly the interaction between teachers and students was reduced, not fully communication (Wallace "et al."). However, even in classes with large number of students there are various classroom techniques suggested for introducing and promoting this approach. According to Richards (1990), organizing the class into groups and pairs is one of the several techniques employed for large classes.

Broadly speaking, educators and researchers from diverse philosophical perspectives have debated on the relationship between class size and student learning at length. Although many studies have found a relationship (e.g. Willms, 2000), class size has not consistently been linked to student achievement (Rutter, 1979, cited in Pennycuick, 1993), in language teaching classrooms. This may be due to the fact that many schools and classrooms have not yet adopted the more demanding but higher quality learner -centered learning practices. Hence, the effective practice of learner-centered approach in speaking teaching classrooms was significant to develop speaking skill achievement of students in large classes. Xiufen (2010:39) writes that "it is not the number of students that is the determinant of success...teachers' management and administration of the classroom activities is of key importance". Therefore, it seems that in classrooms with a large number of students teachers may also have advantages if they spare more efforts to use communicative activities effectively. For example, the presence of large class size can make group work more effective, because when doing group work students can learn to share responsibilities and help each other. This may bring up the flow of different ideas and real life communication so that the teacher responsibility shifts to monitoring and guiding the students.

\section{E. Seating Arrangement}

Participants demonstrated that students, benches and desks were not suitable to carry out speaking activities in a learner-centered approach. For example, participant from the interview stated:

The seating arrangement of students is not suitable to carryout speaking activities by arranging them in to groups and pairs. The benches are not armchairs or portable, they are arranged in rows, so it is difficult to move them in a class for group or pair works (T1).

One can understand from the above response that the seating arrangement may have an influence on the practice of learner-centered approach, because the furniture in the class was immovable that hinder the use of group or pair work. In the perfect English language teaching classroom, students would have swivel chairs on wheels, so that they could quickly and comfortably change position to face each other for pair work, turn around the other way to form a different pair or group, and turn around to face the teacher whenever necessary, or move into a full circle for a whole-class discussion (Johnson and Morrow, 1981; Jones, 2007).

But results of classroom observation showed that classrooms have furniture that was not easily moveable; 
students were seat in rows, with seats facing the front. And the classrooms were overcrowded which left no place for the teachers to move around. Thus, the observation results were similar with the participants response, that is; seating arrangement in these classrooms was organized in long rows with fixed furniture and such classroom lay out could impede an interaction among students, and between students and the teacher.

However, in such cases, teachers were expected to think creatively about seating arrangements to ensure students can speak comfortably. That means, even if we cannot move the furniture, the students can move so that teachers can arrange students in to groups or pairs. Jones (2007:37) argues that learner-centered approach "can be even practiced in language classes where the seating arrangements are in long rows and the furniture is not movable". For example, for pair work, students sitting side-by-side can move their upper bodies to face each other. With groups of three sitting in row, the middle student can move back slightly, so that the ones on the left and right can see each other. On the other hand, groups of four may be less comfortable because two of them will have to move back, but groups of four could consist of two students from the row in front and two from the row behind; then they can all see one another. Therefore, teachers can be able to adopt active teaching if they creatively manage their classroom despite the presence of immovable furniture. Accordingly a participant from the written reflection has written the following:

The seating arrangement is not appropriate, because the benches are not movable. But I do not consider this problem as a big challenge because I arrange students in to groups with students next to them. The group work has helped me a lot to minimize the impact of this problem in teaching speaking skill (T7).

This may imply the determination of the teacher to create interactive classroom learning even if the seating arrangement was not suitable. Classroom observation results also shows that the teacher (T7) was able to sustain learner-centered teaching with the use of group work. This participant was observed when he involve his students from the introduction part of the lesson by asking open-ended questions, and then give time for students to discuss in a group so as to make them think and respond. This was important as it contribute for creating an atmosphere that encourages students' involvement in the discussion. The students were made to form group by moving front row students to face students behind the back row. During group work the teacher go around the class to monitor all groups while they are working together and as such there is active participation of students during whole class discussion. However, other observed participants (T2, T5) were not seen using their own creativity to arrange students in to groups; rather they dominate most of the classroom talk.

Thus, these results may indicate the absence of appropriate classroom practices to practice the learnercentered approach. That mean, results of the study showed that, classrooms seating arrangement were organized in long straight rows with immovable furniture, and it was not suitable for carrying out the learner-centered approach. This finding was consistent with previous study by Derebssa (2005) that reveals the seating arrangement in primary schools does not allow employing the learner-centered approach.

\section{F. Lack of Teaching Materials}

Providing students and teachers with appropriate language learning and teaching resources was important for the effective practice of learner-centered approach. Especially students need to have enough learning resources at hand, such as textbooks, pictures, and cards in order to make students active participants in their learning and in turn teachers will be able to adopt the learner -centered approach. Accordingly lack of teaching materials was raised by participants as a challenge and this was discussed by a participant in the interview as follows:

...the classrooms are not equipped with audio-visual materials that will assist our teaching in a learner-centered approach. This problem has affected our teaching because these facilities would have helped me to make speaking lessons more attractive and learner-centered (T6).

One can understand from the above reflection that the absence of classrooms properly organized with audio-visual facilities can have it is own impact on the teaching of speaking lessons in a learner -centered approach. Language laboratories can be helpful for the teaching of speaking lessons, that is, in such classrooms students can work on their own, in pair or in groups. This can give students the opportunity to practice speaking through different communicative activities. Another participant raised lack of reference books on teaching methodologies as a challenge for applying learner-centered approach and the following quote taken from written reflection:

When I learned in university I have the access to many reference books on English teaching methodologies, but now I have no access to them in my school and even I cannot get them on market... I suggest that at least these books must be photocopied and distributed to schools so that we can read and use them. I think if teachers get access to such reference books they can read and understand as well as able to improve their teaching methodology because at this level teachers can teach themselves. (T3)

This is a typically significant reflection that might indicate the teacher's commitment to develop their skill of learner-centered teaching methodologies, but the absence of reference books and other related teaching aid materials have affected their teaching as well as their up-going or lifelong professional development. 
Many language scholars (e.g., Hedge 2004; Harmer 2006) suggested that there was much to be learnt from the various methodology books, journals, published action researches, and magazines produced for English teachers. The availability of such resources will, therefore, provide teachers with a range of possibilities to develop their skill, and to formulate different kinds of student-centered activities for the teaching of speaking skill (Rutto, 2005; Taylor, 1983). But, the analysis of data gained from the classroom observations showed that the teaching and learning resources were not adequate for employing learner-centered approach in teaching speaking skill. Despite this problem, however, it would have been possible for teachers to use the textbook creatively in a way that promote learner-centered learning and teaching, and improve students speaking skill.

In summary, the results from the participants of the study seem to indicate that teachers were not implementing the learner-centered approach to the desired level indicated in the policy. As can be seen from analyses and discussion in section 1 and section 2 of this chapter, the teachers seemed to have relatively good orientations about the learner-centered approach. However, what can be understood here is that, even if these teachers claimed learner-centered approach was far better than the teacher-centered approach, their actual classroom practices were still characterized by the teacher-centered approach. Inadequate training, time constraints, students' background, class size, and seating arrangement were major challenges teachers raised that have impeded effective implementation of learner-centered approach in teaching speaking skill.

\section{Summary}

This research endeavored to examine the factors that obstruct the practice of learner-centered approach in teaching speaking skill in three government primary schools of Wolaita Sodo City. Of paramount importance was to explore challenges teachers face in practicing learner-centered approach and provide recommendations on how to improve the teaching of speaking skill. The study was a descriptive one that used a qualitative methods and data to explore, analyze, interpret and better understand the complex reality of the situation that have been studied from the teachers' perspective. Comprehensive sampling strategy was used to select participants in the interview and written reflection data gathering processes. Random sampling strategy was used to select one classroom from each school for classroom observation. The study, therefore, employed interview and written reflection as a major data gathering tools, and classroom observation was used to supplement the major data. Accordingly, the data obtained from these tools were processed in order to answer the research questions of this study. This research instruments were helpful in providing significant information about the challenges teachers face in practicing learner -centered approach. A thematic system, based on inductive data analysis process, developed by the researcher was used to code, classify, and sort out actual words from the participants. Thus, the researcher analyzed and categorized the information discussed qualitatively. The results of the study shows that currently the learner-centered approach was not exercised by teachers in teaching speaking to the level that the policy advocates.

\section{Conclusions}

The results indicated that the teachers were not provided with adequate skill or trainings on how to put learnercentered approach in to practice. The findings of the study showed that participants received no specific preservice trainings on how to apply learner-centered approach in their classroom. The implications of these findings was that teachers should be armed with sufficient knowledge to practice learner-centered approach in their teaching which could be necessary to improve the current teaching method in order to develop students English speaking skill. Because the evidence from the study indicates that without having adequate trainings about incorporating learner-centered approach in their speaking teaching classrooms, it could be impossible for the teachers to realize learner-centered approach in their classroom teaching. Other major constraints inhibiting the successful practice of learner-centered approach in teaching speaking skill were time constraints; students background; large class size; seating arrangement; and lack of teaching materials. The analysis of the observations indicated that most of the challenges forwarded by teachers do exist in the actual classrooms. Almost majority of the constraints raised by the participants were external or problems that were beyond teachers control. This seems to imply that these factors have resulted in gaps between the education and training policy and the teaching practices of participants in the study. Therefore, the entire results of this study reveal that currently the learner-centered approach was not being practiced to the desired level indicated in the education policy.

\section{Recommendations}

Based on the above findings of the study, the following recommendations have been put forwarded as a remedy for the prevailing problems:

Even if these teachers seem to have some theoretical knowledge about the learner-centered approach, they still seem to have lack of sufficient and appropriate pre-service training on how to apply this approach in English language teaching classrooms. Therefore, it is recommended here that, firstly, teachers should be provided with 
adequate pre-service training on how to employ the learner-centered approach while teaching speaking skill lessons. Secondly, teachers who are already in the profession should also have to get in-service trainings such as workshops, conferences, and seminars to familiarize them with the approach and its practicability.

To make the practice of learner-centered approach more effective by teachers in teaching speaking skill, it is necessary that the school principals, teachers, and parents should work together to find out mechanisms for alleviating the constraints that affect the practice of learner-centered approach, step by step. Besides, due consideration should be given to improve the students background related problems such as lack of selfconfidence and low level of motivation. Therefore, awareness raising programs should be provided to the society on parents' day or by preparing a special program about negative cultural views towards female students speaking.

The Wolaita Sodo city administration education bureau, the schools, teachers, and the society at large should work in collaboration so that teachers and students be able to get reference books as well as other speaking skill teaching and learning materials on time and adequately.

It is advisable that teachers should be given reasonable class periods to decrease their work load, that could help them to work creatively for using more active speaking teaching activities in their own classroom context.

Teachers should also work both individually or collaboratively to find out effective ways of practicing communicative speaking activities despite the influence of immovable furniture. For example, teachers can use group or pair work by arranging students in two rows to face each other or by moving students outside classroom to form a better collaborative speaking learning.

Finally, in order to minimize students' dependence on mother tongue and to develop a good speaking learning atmosphere in the classroom teachers need to persuade their students that they will benefit from speaking English in the classroom. Besides teachers need to encourage, motivate, and support students to use English through engaging them in different communicative activities.

\section{REFERENCES}

Brown, H. D., 1994. Teaching by Principles: An Interactive Approach to Language Pedagogy. New Jersey: Prentice Hall Regent.

Burns, A., and Joyce, H. 1997. Focus on speaking. Sydney: National Center for English Language Teaching and Research.

Cooper, J.L., and Robinson P., 2000. Getting Started: Informal Small-group Strategies in Large Classes. Oxford University Press.

Derebssa Dufera Serbessa, 2005. Quality of Teaching and Learning in Ethiopian Higher Education: Tension between Traditional and Innovative Teaching Approaches. Published by CICE Hiroshima University, Journal of International Cooperation in Education, Vol.9, No.1, 2006 pp.123 - 140 http://home.hiroshimau.ac.jp/cice/paper68.pdf.

Dorneyeize .Z, and Thurrell .S., 1994. Teaching Conversational Skills Intensively: course content and rationale. ELT Journal 48.(1). 40-49.

Harmer J., 2006. The Practice of English Language Teaching. Longman publication: Malaysia.

Hedge .T. 2004. Teaching and Learning in Language Classroom. Oxford: OUP

Hymes, , D., 1970. On Communicative competence. New York: Holt, Rinehart \& Winston. .

Johnson, K., \& Morrow, K. 1981. Communication in the classroom. London: Longman.

Jones L., 2007. The Student-Centered Classroom. Cambridge University Press, New York.

Lea, S. J., D. Stephenson, and J. Troy, 2003. Higher Education Students' Attitudes to Student-Centered Learning: Beyond 'educational bulimia'. Studies in Higher Education, Vol. 28.

http://taylorandfrancis.metapress.com/media/1a48dgtttl2jv334gt7r/contributions/c/k/x/d/ckxd4gr945glcgaj.pdf.

Morgan, D. (1996). Focus groups. Annual Review of Sociology, 22, 129-152.

Nespor, J., 1987. The role of beliefs in the practice of teaching. Journal of Curriculum Studies, 18, 197-206. http://www.storycenter.org

O'Neill, G., and McMahon, T. 2005. Student-centered learning: What does it mean for students and lecturers? http://www.aishe.org/readings/20011-1/

Patton, M. Q. 1990. Qualitative evaluation and research methods. Newbury Park, Calif.: Sage.

Paulston, C. B., and Bruder, M. N. 1976. Teaching English as a second language: Techniques and procedures. Cambridge, Massachusetts: Winthrop Publishers, Inc.

Pennycuick, D., 1993. School effectiveness in developing countries: A summary of the research evidence. Serial no. 1. London: Department for International Development Education Division.

QU Xiufen, 2010.Teaching English to Large Classes in the Context of Curriculum Standard.

Richards, Jack C., 1990. Conversationally speaking: Approaches to the teaching of conversation. New York: Cambridge University Press.

Richards, J. C., 2006(a). Communicative language teaching today. New York: CUP. 
Richards, J.C., 2006(b). Teaching Listening and Speaking From Theory to Practice. Cambridge University Press, New York. www.cambridge.org

Richards, J. C., and Rodgers, T. 1986. Approaches and methods in language teaching: A descriptive analysis. Cambridge: Cambridge University Press.

Rutter, M., 1979. Fifteen thousand hours: Secondary schools and their effects on children. London: Open Books. http://www.storycenter.org

Savignon, S. 2002. Communicative Curriculum Design for the 21st Century. Mass: Addison-Wesley. 40/1: 2-7.

Schmitt N., 2002. An Introduction to Applied Linguistics. London, Arnold.

Skehan, P., 1996. A Framework for the Implementation of Task-based Instruction. Applied Linguistics. $\mathrm{http} / / \mathrm{www}$. skills4study.com

Taylor, B. P. 1983. Teaching ESL: Incorporating a communicative, student-centered component. TESOL Quarterly. http://www.ascilite.org.au/conferences/adelaide96/papers/21.html

Tirualem Ayalew, 2003. The classroom practices of learner-centered approach in second cycle primary schools of Addis Ababa. A thesis submitted to the school of Graduate studies of Addis Ababa University.

Thompson, G. 1996. Some misconceptions about communicative language teaching. ELT Journal 50/1: 9-15.

UNICEF ,2000. Defining Quality Education. Curriculum report card. Working Paper Series, Education Section, Programme Division. New York. http// www. unescobkk. Org

Ur, P. (1996). A course in language teaching. Cambridge: CUP.

Verwimp, P., 1999. Measuring the quality of education at two levels: A case study of primary schools in rural Ethiopia. International Review of Education, 45(2): 167-196

http://www.ncrel.org/sdrs/areas/issues/content/contareas/science/sc31

Wallace.T., Stariba.W.E., and Walberg.H.J., 2004. Teaching Speaking, Listening, and Writing. IBE. http://www.curtin.edu.au/curtin/dept/smec/iae

Widdowson, H .G., 1978. Teaching Language as Communication. Oxford: OUP.

Willms, J. D. (2000). Standards of care: Investments to improve children's educational outcomes in Latin America. Paper presented at the "Year 2000 Conference of Early Childhood Development" sponsored by the World Bank, Washington, D.C., April, 2000.

Zwiers, J., 2007. Professional Development for Active Learning in Sub-Saharan Africa: Reflectively Practicing a Community-centered Approach. Journal of Education for International Development 3:1 8-12. www.jeffzwiers.com. 